\title{
Membrane attack complex inhibitor CD59a protects against focal cerebral ischemia in mice
}

\author{
Denise Harhausen ${ }^{1}$, Uldus Khojasteh', Philip F Stahel ${ }^{2}$, B Paul Morgan ${ }^{3}$, Wilfried Nietfeld ${ }^{4}$, Ulrich Dirnagl ${ }^{1}$, \\ George Trendelenburg ${ }^{1 *}$
}

\begin{abstract}
Background: The complement system is a crucial mediator of inflammation and cell lysis after cerebral ischemia. However, there is little information about the exact contribution of the membrane attack complex (MAC) and its inhibitor-protein CD59.

Methods: Transient focal cerebral ischemia was induced by middle cerebral artery occlusion (MCAO) in young male and female CD59a knockout and wild-type mice. Two models of MCAO were applied: 60 min MCAO and 48 $\mathrm{h}$ reperfusion, as well as 30 min MCAO and $72 \mathrm{~h}$ reperfusion. CD59a knockout animals were compared to wild-type animals in terms of infarct size, edema, neurological deficit, and cell death.

Results and Discussion: CD59a-deficiency in male mice caused significantly increased infarct volumes and brain swelling when compared to wild-type mice at $72 \mathrm{~h}$ after 30 min-occlusion time, whereas no significant difference was observed after $1 \mathrm{~h}$-MCAO. Moreover, CD59a-deficient mice had impaired neurological function when compared to wild-type mice after 30 min MCAO.
\end{abstract}

Conclusion: We conclude that CD59a protects against ischemic brain damage, but depending on the gender and the stroke model used.

\section{Background}

Focal cerebral ischemia leads to a primary brain damage which results from a complex pattern of pathophysiological events including excitotoxicity, periinfarct depolarizations, and inflammation [1-4]. The complement cascade is an important part of the innate immune system and is a potent mediator of inflammation and cell lysis which is activated following cerebral ischemia [5-7], and strong complement activation after ischemic stroke is associated with unfavourable outcomes [8]. Complement is deposited on apoptotic neurons which likely leads to injury in adjacent viable cells. Different studies show that blocking the complement system during the early phase of infarct evolution protects the penumbra and reduces brain injury $[9,7,10]$. The complement regulatory molecule CD59 represents the major controller of membrane attack complex (MAC) formation, and is an essential protector of homologous cells after complement

\footnotetext{
*Correspondence: george.trendelenburg@charite.de
'Experimentelle Neurologie, Charité-Universitätsmedizin Berlin, CCM, 10117,

* Correspondence: george.trendelenburg@charite.de
'Experimentelle Neurologie, Charité-Universitätsmedizin Berlin, CCM, 10117, Berlin, Germany
} Berlin, Germany cystein residues which form five disulfide bonds [12]. It regulates the complement activation cascade at the final step inhibiting formation of the MAC [13]. CD59 is anchored to the cell membrane via glycosyl phosphatidyl inositol (GPI), and expressed ubiquitously on cells which are in contact with body fluids containing components of the complement system including cells in the CNS. Numerous studies indicate that the MAC not only induces cell lysis but also transduces cell activation when assembled in sublytic concentrations on cell membranes [14]. For instance, the MAC has been shown to trigger the up-regulation of P-selectin and the secretion of von Willebrand factor in endothelial cells [15]. Moreover, formation of MAC was shown to trigger endothelial damage, cytotoxicity, and neurodegneration in vivo $[16,17]$ and deficient expression of CD59 in a rare human disease (Paroxysmal nocturnal haemoglobinuria) is associated with an increased risk of thrombotic events $[18,19]$. In a model of renal Ischemia/Reperfusion (I/R), it was shown that CD59a plays a protective role in injured 
mice [20]. This leads to the question whether CD59a may also play a protective role in cerebral ischemia.

CD59a is constitutively expressed in neurons, most probably to protect from so-called autologous "innocent bystander" cell lysis after complement system activation in brain injury [21,22]. Nevertheless, because of low levels of neuronal CD59a expression, the neuronal capacity of controlling activation of complement is limited. This renders neurons susceptible to MAC-driven lysis in conditions of intracerebral complement activation [11]. Previous in vitro experiments, as well as immunostaining of human brains suggested that oligodendrocytes can also express low levels of CD59a [21]. CD59aknockout mice [18] had a significantly impaired neurological outcome after experimental closed head injury and showed a significant exacerbation of cerebral damage when compared to wild-type controls [11].

Taken together, there is data supporting a protective effect of CD59a in cerebral ischemia which led us to the present study, in which we analysed the role of CD59a in two different standard experimental stroke models by the use of CD59a knockout mice.

\section{Methods}

\section{Animals}

Generation and characterization of CD59a knockout mice was described by Holt et al. (2001) [18]. CD59a-/- mice were generated on a mixed $129 / \mathrm{Sv} \times \mathrm{C} 57 \mathrm{Bl} / 6$ genetic background and have been backcrossed to the original $\mathrm{C} 57 \mathrm{Bl} / 6$ background for more than 10 generations. Agematched 10 - 12 week old C57Bl/6 mice (BfR, Berlin, Germany) were used as control mice. The animal handling and surgery were performed in accordance with the Guidelines for the Use of Animals in Neuroscience Research (Society for Neuroscience). All experiments were approved by the local institutional Animal Care Committee, LAGeSo (No.G0382/05). The mice were bred in a selective pathogen-free (SPF) environment and under standardized conditions of temperature $\left(21^{\circ} \mathrm{C}\right)$, humidity $(60 \%)$, light and dark cycles (12:12 h), with food and water provided ad libitum.

\section{Induction of focal cerebral ischemia}

Middle cerebral artery occlusion (MCAO) was induced by inserting a silicone-coated $8 / 0$ nylon monofilament (Xantopren M Mucosa and Activator NF Optosil Xantopren, Heraeus Kulzer, Wehrheim, Germany) via the internal carotid artery as described by Hara et al. (1996) [23]. Sufficiency of occlusion and reperfusion of the middle cerebral artery (MCA) was monitored by Laser Doppler flowmetry (Peri Flux 4001 Master, Perimed, Stockholm, Sweden). Mice were anaesthetized with $2 \%$ isoflurane for induction and maintained with $1.5 \%$ isoflurane in $70 \% \mathrm{~N} 2 \mathrm{O}$ and $30 \% \mathrm{O} 2$ via a face mask.
Anesthesia did not exceed 10 minutes. We used two different MCAO- models, one with a short ischemic interval (30 min) and $72 \mathrm{~h}$ of reperfusion [24], as well as one with a more prolonged occlusion $(60 \mathrm{~min}$ and $48 \mathrm{~h}$ of reperfusion). Thirty minutes of $\mathrm{MCAO}$ leads to selective neuronal injury and pronounced inflammation in the striatum with little involvement of neocortical structures, while 60 min MCAO produces extensive striatal and neocortical infarction. After 30 minutes ('mild model'), or $1 \mathrm{~h}$ ('severe model') of ischemia the animals were re-anaesthetized and the filament was removed to permit reperfusion. During surgery and ischemia, body temperature was controlled by a temperature feedback controlled heating plate and maintained between 37.0 and $37.5^{\circ} \mathrm{C}$. There was no significant difference of the mean body weight between the different groups. All experiments were performed in a randomized manner by investigators blinded to the groups as described and recommended recently by Dirnagl et al. (2009) [25].

\section{Neurological score}

The neurologic dysfunction was determined using a neurological score (NSC) described by Bederson [26] and modified by Hara [23]. Neurological deficits were graded in wild-type and CD59a knockout mice after MCAO on a scale of: 0 - no deficit/1- failure to extend right forepaw/2 - circling to the contralateral side/3 - loss of postural reflex/4 - death. The NSC was assessed at the time-points $24 \mathrm{~h}, 48 \mathrm{~h}$ and $72 \mathrm{~h}$ after induction of cerebral ischemia for $30 \mathrm{~min}$ (mild model), or 1 hour (severe model). Task performance was evaluated in a blinded fashion with regard to the animal groups. Differences between wild-type and CD59a-knockout mice were analysed statistically by the Mann-Whitney U test.

\section{Assessment of infarct volume}

Two (60 min MCAO), or three (30 min MCAO) days after induction of ischemia, mice were deeply anaesthetized and sacrificed. The brains were removed rapidly from the skull and snap frozen in 2-methylbutane on dry ice. Brains were sectioned $(12 \mu \mathrm{m})$ on a cryostat in different coronal cryosections (positions see below), dried overnight, and stained with hematoxylin (Merck, Darmstadt, Germany). The sections were digitized, the area of infarction was quantified by using Sigma Scan Pro; Version 5.0.0 Software (Jandel Scientific, San Rafael, CA, USA), and infarct volumes were calculated. Brain swelling was calculated by subtracting the size of the whole contralateral (non-infarcted) hemisphere from the whole ispilateral (infarcted) hemisphere. Animals without an infarct or with only a small infarct in the hippocampus were excluded from these measurements because insufficient induction of cerebral ischemia was assumed. Infarct sizes of male, female, or mixed gender CD59a-deficient 
mice were compared to the infarct sizes of wild-type animals with matching gender. Statistical analysis was performed by using the Mann-Whitney-U-Test.

\section{Genotyping}

Every knockout mouse used in this study was genotyped before use, which was performed using the REDExtractN-Amp Tissue PCR kit (Sigma-Aldrich) with DNA extracted from mice tails and the following primers: Intron 3 (5'-GGT GAC CAA CTG GTG TTA ACA AAG GG-3'), neomycin '- (5'-GAA CCT GCG TGC AAT CCA TCT TG-3'), and exon 3-(5'GCT ACC ACT GTT TCC AAC CGG TG-3'). Amplification of the wild-type gene resulted in an amplicon of $212 \mathrm{bp}$, DNA derived from CD59a-ko mice produced an amplicon of $450 \mathrm{bp}$.

\section{Immunohistochemistry}

Immunohistochemistry was performed on fresh frozen tissue harvested at different times of reperfusion. From fresh frozen tissue $12 \mu \mathrm{m}$ coronal cryosections at interaural positions $6.6,5.3,3.9,1.9$, and $0 \mathrm{~mm}$ were thawmounted onto glass slides. Adjacent sections were used to determine stroke volume (see above). Slides were airdried and fixed in $-20^{\circ} \mathrm{C}$ methanol and acetone (1:1). The sections were incubated in blocking solution containing 3 $\%$ normal goat serum and $0.3 \%$ Triton X-100 (Sigma). The slides were incubated $2 \mathrm{~h}$ at room temperature with a polyclonal rat anti-CD11b antibody (Chemicon) which stains macrophages/monocytes and microglia. For the detection of primary antibody, slides were incubated with Cy3-conjugated goat anti-rat IgG (Invitrogen) at 1:400 for $1 \mathrm{~h}$ at room temperature. Slides were also counterstained with Hoechst 33258, which stains DNA (Invitrogen $\mathrm{GmbH}$; Karlsruhe, Germany). The whole ipsilateral hemispheres of three sections each animal $(n=3)$ were counted using stereo investigator 7 (MicroBrightField Bioscience, Williston, USA).

\section{Terminal deoxynucleotidyl transferase dUTP nick end labeling (TUNEL)}

The Fluorescein in Situ Cell Death Detection Kit (Roche Diagnostics GmbH, Mannheim, Germany) was used for TUNEL stain. Adjacent slides for immunohistochemical staining (see above) were used for the detection of damaged cells. Slides were dried and fixed in $4 \%$ formalin solution. After washing, the sections were incubated in ice-cold ethanol-acetic acid solution (3:1) for $10 \mathrm{~min}$ followed by incubation for $1 \mathrm{~h}$ in 3\% Triton-X 100 (Sigma-Aldrich). Next, sections were incubated with TdT-enzyme in reaction buffer containing fluoresceindUTP for $90 \mathrm{~min}$ at $37^{\circ} \mathrm{C}$. Enzyme was omitted for the negative control. After washing, slides were also counterstained with Hoechst 33258 (Invitrogen GmbH; Karlsruhe, Germany). All sections were evaluated after staining using Leica stereo investigator 7 (MicroBrightField Bioscience, Williston, USA).

\section{Statistical analysis}

For comparison of infarct volumes and neurological deficit Mann-Whitney-U-test was used, if not stated otherwise. P-values below 0.05 were considered statistically significant. Power calculation was performed using SISA-Binominal [27]. Based on the known variance of previous experiments the MCAO experiments were powered $(\alpha=0.05 ; \beta=0.8)$ to detect effect sizes $d$ [28] of at least 1 , i.e. of one standard deviation.

\section{Results}

CD59a-deficiency increases infarct volume in mild experimental stroke, but not in the more severe stroke model

First, we analysed whether CD59a-deficiency alters the size of the infarcted area in two different models of cerebral ischemia: a more severe stroke model $(60 \mathrm{~min}$ occlusion time) and a mild one (30 min occlusion time).

When infarct volumes of male and female CD59adeficient mice and matching wild-type mice were compared after $1 \mathrm{~h} \mathrm{MCAO}$ and $48 \mathrm{~h}$ of reperfusion, no significant difference between CD59a-knockout mice and wild-type mice, either in males (values are given as median [25 $5^{\text {th }}$ percentile, $75^{\text {th }}$ percentile]: CD59a $\mathrm{m}^{-/-:} 108 \mathrm{~mm}^{3}$ [96 mm $\left.\mathrm{mm}^{3}, 164 \mathrm{~mm}^{3}\right] ; \mathrm{WT}_{\mathrm{m}}: 129 \mathrm{~mm}^{3}\left[123 \mathrm{~mm}^{3}, 144\right.$ $\mathrm{mm}^{3}$ ], in females (CD59a $\mathrm{a}^{-} /-: 129 \mathrm{~mm}^{3}\left[98 \mathrm{~mm}^{3}, 145\right.$ $\mathrm{mm}^{3}$ ] $\mathrm{WT}_{\mathrm{f}}: 130 \mathrm{~mm}^{3}\left[109 \mathrm{~mm}^{3}, 143 \mathrm{~mm}^{3}\right]$, or in the mixed-gender group was detected (CD59a $\mathrm{amix} /-: 119 \mathrm{~mm}^{3}$ [94 $\left.\mathrm{mm}^{3}, 147 \mathrm{~mm}^{3}\right] \mathrm{WT}_{\text {mix }}: 130 \mathrm{~mm}^{3}\left[113 \mathrm{~mm}^{3}\right.$, $144 \mathrm{~mm}^{3}$ ]) (Figure 1A,C,E). There was also no significant difference of brain swelling after $60 \mathrm{~min}$ MCAO and $48 \mathrm{~h}$ reperfusion between CD59a-knockout and wild-type mice of either gender (median: CD59a $\mathrm{a}_{\text {mix }} / /-: 46 \mathrm{~mm}^{3}$; WT $\mathrm{WT}_{\text {mix }}$ : $56 \mathrm{~mm}^{3}$ ) (Figure 1B,D,F). For Type II error considerations, see Methods (Statistics).

However, when mice were subjected to the second stroke model (30 min MCAO), a statistically significant increase of the infarct volume was observed in male CD59a-knockout mice and in CD59a-knockout mice of mixed gender when compared to wild-type mice at $72 \mathrm{~h}$ of reperfusion (difference of the infarct volume in the mixed gender group, given as median $\left[25^{\text {th }}\right.$ percentile, $75^{\text {th }}$ percentile]: CD59a $\mathrm{a}_{\text {mix }}-1-: 74 \mathrm{~mm}^{3}\left[57 \mathrm{~mm}^{3}\right.$, $\left.113 \mathrm{~mm}^{3}\right] ; W_{\text {mix }}$ : $57 \mathrm{~mm}^{3}\left[23 \mathrm{~mm}^{3}, 87 \mathrm{~mm}^{3}\right.$ ]; $\mathrm{p}=0.029$ ) (Figure $2 \mathrm{~A}$ ). The difference was statistically significant only in male mice (infarct volume in male mice: CD59a $\mathrm{a}^{-/-} 77 \mathrm{~mm}^{3}\left[57 \mathrm{~mm}^{3}, 112 \mathrm{~mm}^{3}\right]$ vs. $\mathrm{WT}_{\mathrm{m}}$ : $46 \mathrm{~mm}^{3}\left[20 \mathrm{~mm}^{3}, 74 \mathrm{~mm}^{3}\right] \mathrm{p}=0.020$; infarct volumes in female mice: CD59a $\mathrm{a}^{-} /-60 \mathrm{~mm}^{3}\left[42 \mathrm{~mm}^{3}, 109 \mathrm{~mm}^{3}\right]$ vs. $W_{\mathrm{f}}: 78 \mathrm{~mm}^{3}\left[34 \mathrm{~mm}^{3}, 95 \mathrm{~mm}^{3}\right.$ ]) (Figure 2C,E). Brain swelling correlated with infarct volumes, because brain 


\section{$60 \mathrm{~min}$ MCAO / 48h reperfusion}

\section{infarct volume}
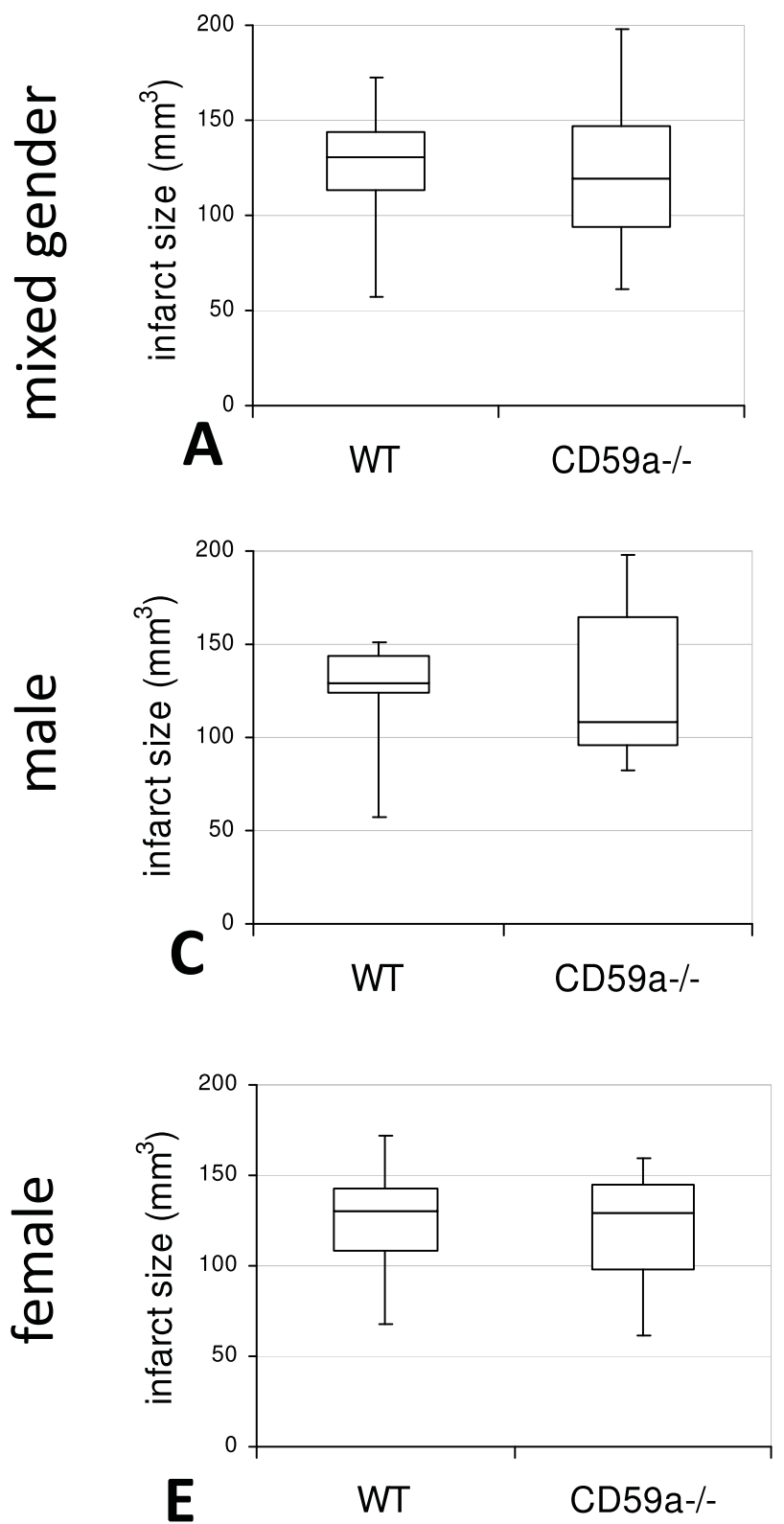

brain swelling
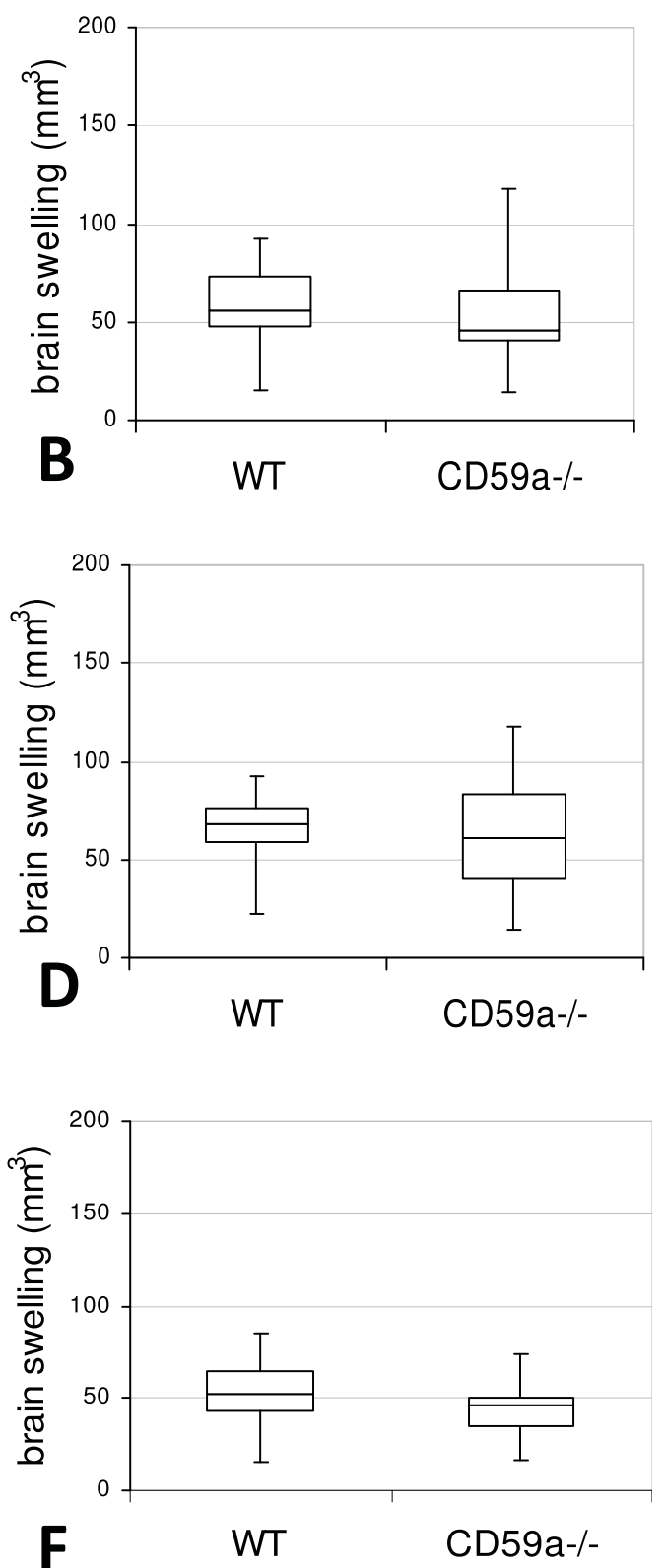

Figure 1 Comparison of infarct volume and brain swelling of CD59a-deficient and wild-type-mice (C57BL/6) after $60 \mathrm{~min} \mathrm{MCAO}$. Infarct volumes $(\mathbf{A}, \mathbf{C}, \mathbf{E})$, and brain swelling $(\mathbf{B}, \mathbf{D}, \mathbf{F})$, given as box-and-whisker plots, at $48 \mathrm{~h}$ of reperfusion after induction of ischemia are visualized for both, CD59a-deficient (CD59a-/-) and wild-type (WT) mice, of both genders (A, B) $\left(n=22_{\text {CD59a- } / \text { mixi }} \mathrm{n}=16_{\text {WT mix }}\right)$ as well as male (C, $\left.\mathbf{D}\right)$

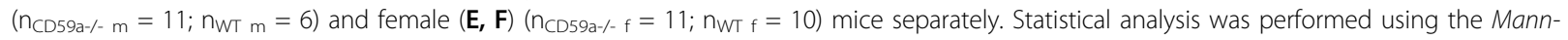
Whitney-U-test. The indirect infarct volume was calculated as the volume of the difference between contralateral hemisphere and the noninfarcted volume of the ipsilateral hemisphere. There is no significant difference between infarct sizes of CD59-ko mice and wild-type mice. In all box plots, the top of the box represents the 75th percentile, the bottom of the box represents the 25th percentile, and the line in the middle represents the 50th percentile (median). The whiskers (the lines that extend out the top and bottom of the box) represent the highest and lowest values that are not outliers or extreme values. 


\section{$30 \mathrm{~min}$ MCAO / $72 \mathrm{~h}$ reperfusion}

\section{infarct volume}
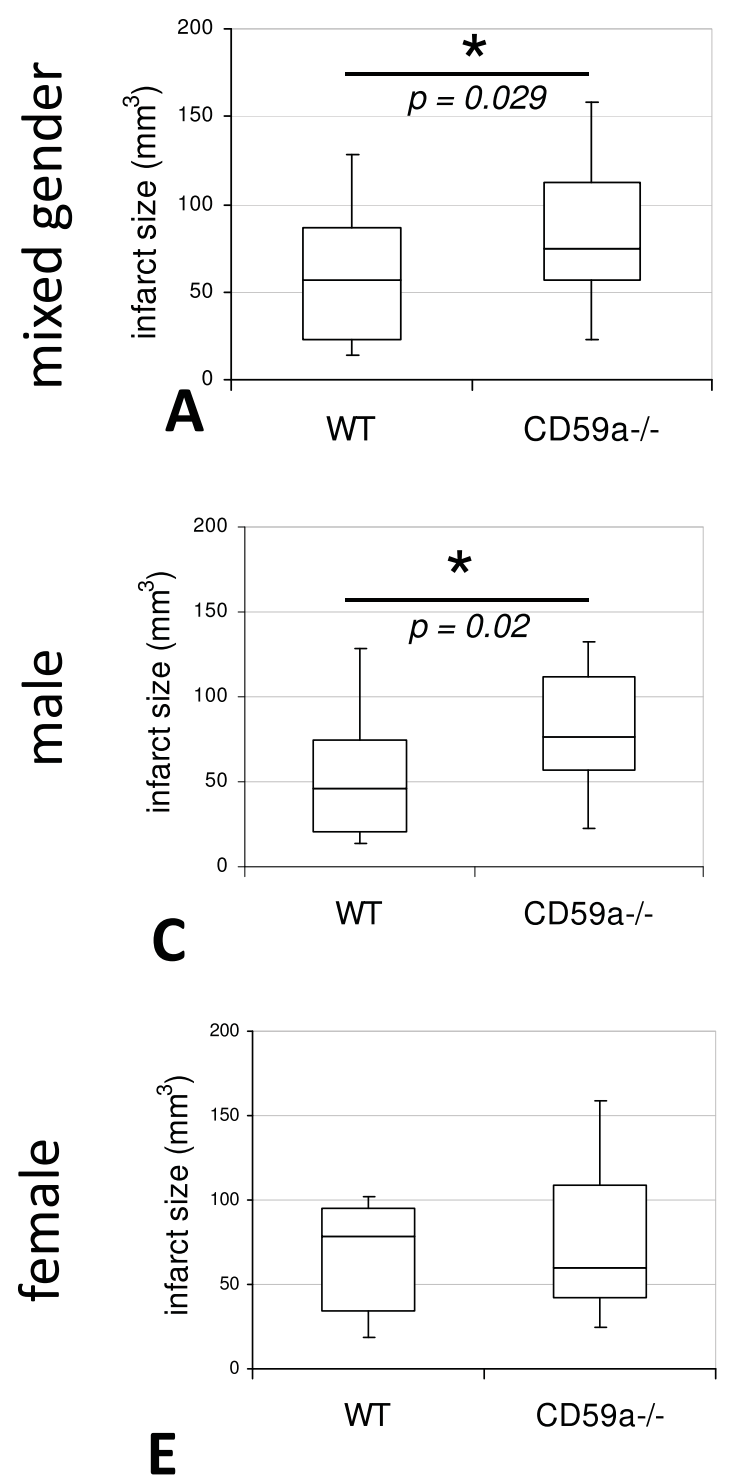

\section{brain swelling}
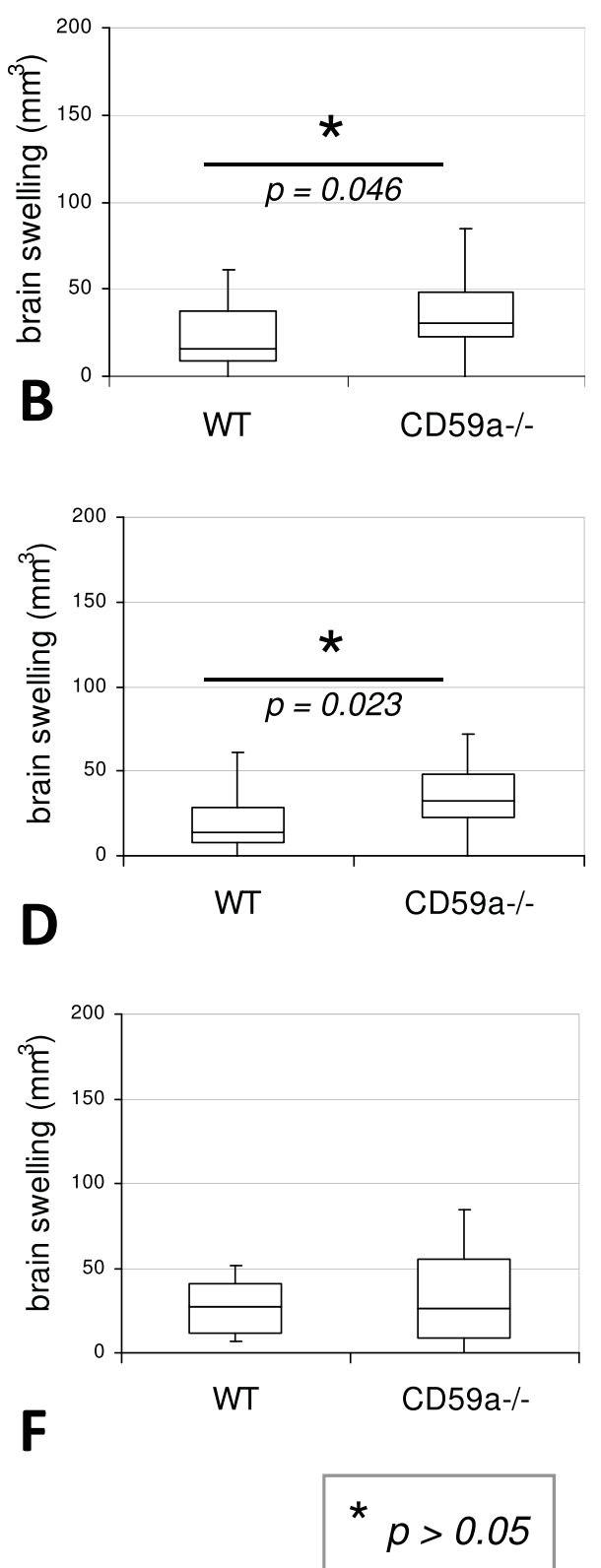

Figure 2 Comparison of infarct volume and brain swelling of CD59a-deficient and wild-type-mice (C57BL/6) after $30 \mathrm{~min} \mathrm{MCAO.} \mathrm{Infarct}$ volumes $(\mathbf{A}, \mathbf{C}, \mathbf{E})$, as well as volume of brain swelling (B, D, F) given as box-and-whisker-plots are visualized. Statistical analysis was performed with the Mann-Whitney-U-test (*: $\mathrm{p} \leq 0.05$ ). In contrast to $1 \mathrm{~h}$ MCAO-model (figure 1), after 30 min MCAO and $72 \mathrm{~h}$ of reperfusion there was a significant difference of infarct volumes and brain swelling between wild-type and CD59a-deficient mice in both, mixed gender and male mice: infarct volumes were larger and brain swelling increased in male CD59a knockout mice $\left(n_{C D 59 a-/ ~} m=22 ; n_{W T} m=18\right)$, as well as in knockout mice of mixed gender ( $n=25_{\text {CD59a- }- \text { mix } i n}=24$ wT mix), when compared to age- and gender-matched wild-type control mice. No significant differences were seen for female mice. In all box plots, the top of the box represents the 75th percentile, the bottom of the box represents the 25th percentile, and the line in the middle represents the 50th percentile. The whiskers (the lines that extend out the top and bottom of the box) represent the highest and lowest values that are not outliers or extreme values. 
swelling - as calculated by the size difference of the ischemic and nonischemic hemisphere - was significantly increased in CD59a-/- male mice (median: CD59a $\mathrm{m}^{-/- \text {: }}$ $33 \mathrm{~mm}^{3}$; $\mathrm{WT}_{\mathrm{m}}: 14 \mathrm{~mm}^{3}$ ) and mixed gender (median: $\mathrm{CD} 9 \mathrm{a}_{\text {mix }}{ }^{-/-:} 31 \mathrm{~mm}^{3}$; WT $\mathrm{Wix}_{\text {mix }}: 16 \mathrm{~mm}^{3}$ ), but not female mice (Figure 2B,D,F).

CD59a-deficiency leads to increased apoptosis only in the more severe experimental stroke

Next, we compared the amount of TUNEL-positive cells in CD59a-deficient and wild-type mice in both models, because we speculated that MAC-inhibition by CD59a may influence the amount of apoptotic cell death, which depends on the stroke model used [24,29]. TUNEL-positive cells were mostly found in the infarct border zone ('penumbra'), the extend and location of which depends on the stroke model used: e.g. compare amount of TUNEL-positive cells in the different sections of both models (Figure 3A,B). Indeed, there was a significant increase of TUNEL-positive cells found in the ischemic hemisphere of male CD59a-deficient mice at $48 \mathrm{~h}$ after 60 min MCAO when compared to wild-type controls (Figure 3 and 4). Since infarct volumes did not differ significantly, this observation argues against a pure 'secondary effect', meaning that the amount of apoptotic cells only depends on the size of the infarct volume. On the other hand, the amount of TUNEL-positive cells did not differ significantly between CD59a-deficient and wild-type mice when the mild stroke model (30 min $\mathrm{MCAO} / 72 \mathrm{~h}$ reperfusion) was used (Figure 3).

\section{CD59 deficiency has no influence on CD11b-positive cell accumulation in post-ischemic brain tissue}

Because sublytic MAC deposition was recently shown to be associated with the release of proinflammatory cytokines (e.g. TNFa) and chemotactic factors (IL-8) [15,30], the post-ischemic inflammatory response was determined in CD59a-deficient mice and wild-type mice by counting CD11b-positive cells in the ischemic hemisphere. Staining with $\mathrm{CD} 11 \mathrm{~b}$, which stains invading macrophages/ monocytes as well as activated microglia, revealed that there was no significant alteration of CD11b-positive cells in the ischemic hemisphere of CD59a-ko mice (section 1: $301 \pm 4$ [ $60 \mathrm{~min} \mathrm{MCAO}$ ], $252 \pm 61$ [30 $\mathrm{min}$ $\mathrm{MCAO}$ ]; section 2: $410 \pm 123$ [60 min MCAO], $365 \pm 96$ [30 min MCAO]); section 3: $600 \pm 342$ [60 min MCAO], $188 \pm 52$ [30 min MCAO]) when compared to that of wild-type mice (section 1: $337 \pm 110$ [60 min MCAO], $162 \pm 102$ [30 min MCAO]; section 2: $530 \pm 197$ [60 min $\mathrm{MCAO}$ ], $437 \pm 34$ [30 min MCAO]; section 3: $575 \pm 286$ [60 min MCAO], $259 \pm 102$ [30 min MCAO]) in both models ( $48 \mathrm{~h}$ after $60 \mathrm{~min} \mathrm{MCAO} ; 72 \mathrm{~h}$ after $30 \mathrm{~min}$ MCAO) (data not shown).

\section{CD59a-deficient mice have a worse neurological deficit} when compared to wild-type mice after 30 min MCAO To investigate if CD59a-deficiency also influences the neurological outcome after cerebral ischemia, CD59aknockout as well as wild-type control mice of mixed gender were subjected to experimental stroke with two different occlusion times (MCAO for $30 \mathrm{~min}$, respectively $60 \mathrm{~min}$ ). The neurological deficit was determined at different times of reperfusion after induction of cerebral ischemia.

Neither at $24 \mathrm{~h}$ nor at $48 \mathrm{~h}$ reperfusion time was there a significant difference of the neurological deficit between CD59a-ko $(\mathrm{n}=24)$ and wild-type mice $(\mathrm{n}=21)$ when middle cerebral artery was occluded for $60 \mathrm{~min}$ (Figure 5).

However, in contrast to the findings with the more severe stroke model, a significant neurological deterioration $(\mathrm{p}<0.05)$ was observed after 30 min occlusion of the middle cerebral artery (mild stroke model) in

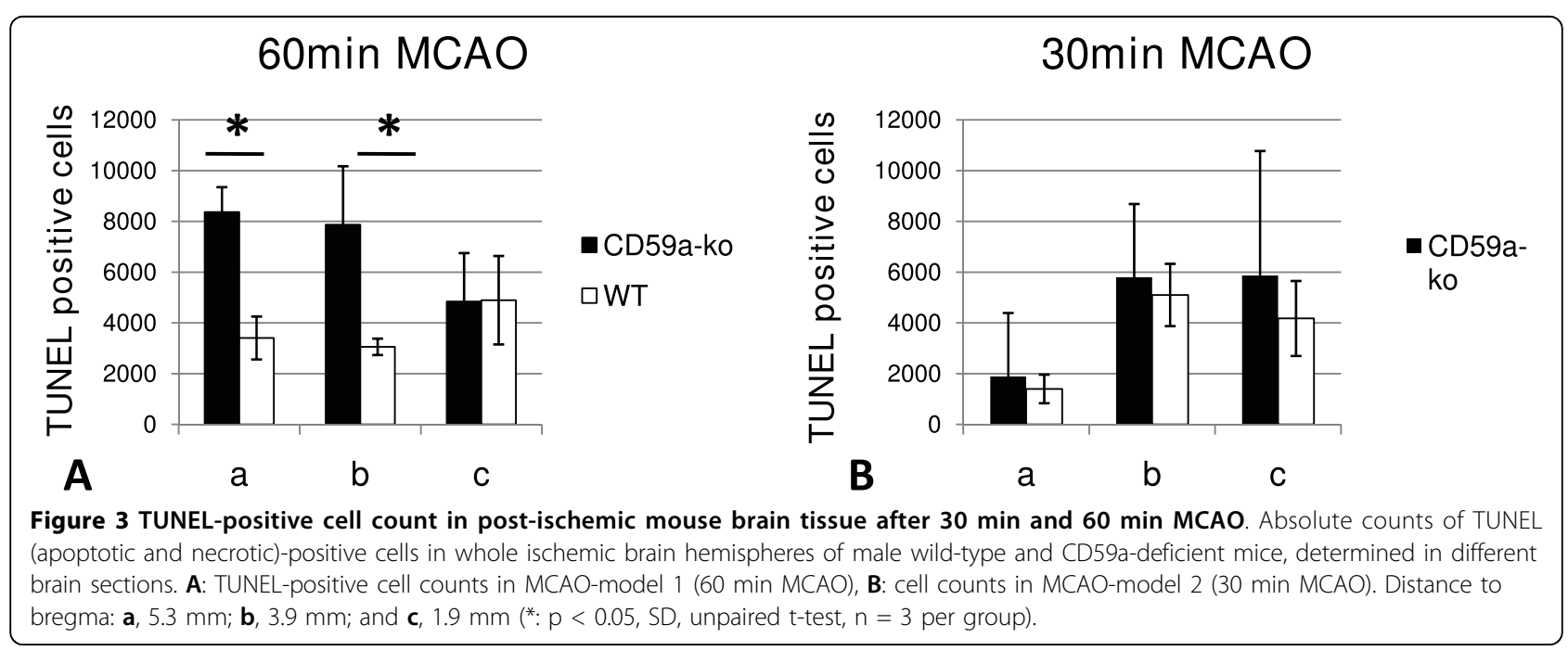




\section{$1 \mathrm{~h} \mathrm{MCAO} \mathrm{/} \mathrm{48h} \mathrm{reperfusion}$}
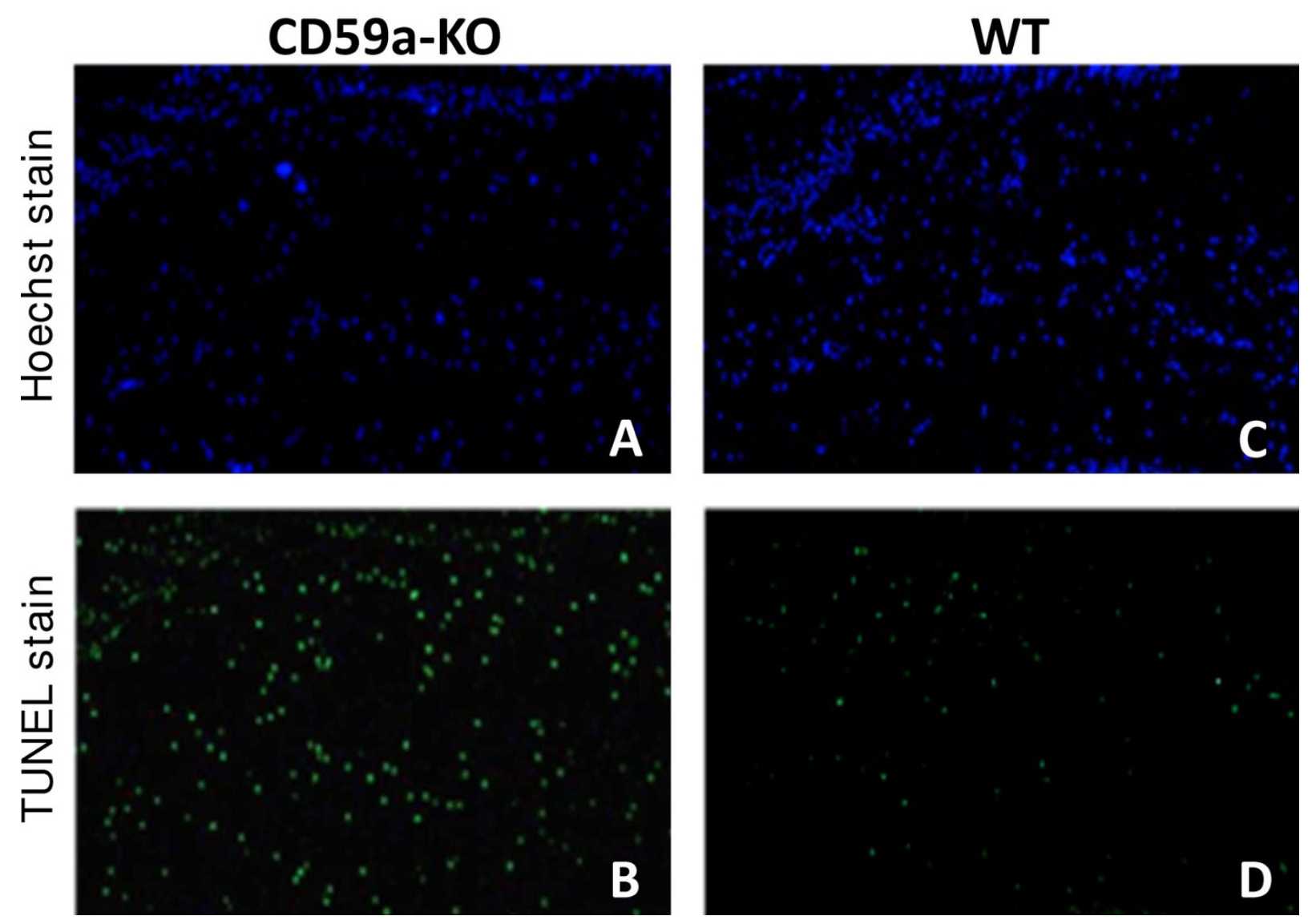

Figure 4 Representative images of TUNEL-positive cells in post-ischemic mouse brain tissue after 60 min MCAO and $48 \mathrm{~h}$ reperfusion TUNEL (apoptotic and necrotic)-positive cells $(\mathbf{B}, \mathbf{D})$ in ischemic brain tissue of the infarct border zone (penumbra) of male wild-type (C, D) and CD59a-deficient mice (A, B). A,C: staining of cell nuclei using Hoechst 33258, which stains DNA (Invitrogen, Germany).

CD59a-deficient mice of mixed gender and male gender when compared to the wild-type mice. At all three time points examined $(24 \mathrm{~h}, 48 \mathrm{~h}$, and $72 \mathrm{~h}$ after induction of $\mathrm{MCAO}$ ), there was a significant increase in the neurological deficit $\left(\mathrm{p}_{24 \mathrm{~h}}=0.047 ; \mathrm{p}_{48 \mathrm{~h}}=0.014 ; \mathrm{p}_{72 \mathrm{~h}}=0.025\right.$ as calculated by Mann-Whitney U test) in CD59a-deficient mice $(\mathrm{n}=27)$ when compared to wild-type control mice $(\mathrm{n}=27)$. Male mice showed only a significant difference after $48 \mathrm{~h}$ and $72 \mathrm{~h}\left(\mathrm{p}_{48 \mathrm{~h}}=0.0042 ; \mathrm{p}_{72 \mathrm{~h}}=0.007\right)$ (Figure 6).

\section{Discussion}

This study demonstrates that deficiency of the complement regulator protein CD59a exacerbates post-ischemic brain damage in vivo in a gender-specific way and depending on the severity of the stroke.

The complement system has been recently identified as a conductor of inflammation triggering further tissue damage in experimental ischemia [31]. Activation of the complement system mediates secondary brain injury, which leads to increased infarct volumes, a pronounced inflammatory response, and a worse neurological deficit $[32,33]$. Recent studies indicated that both, the classical and the mannose-binding lectin (MBL) complement pathways trigger complement activation $[6,34,35]$, but the alternative pathway also appears to play a crucial role in neuronal death $[36,37]$. Complement activation results in the release of chemotactic factors (e.g. C3a, C5a) and finally in the formation of the terminal poreforming complex, the membrane attack complex (MAC), by complement components C5b-9. Formation of sublytic concentrations of the MAC was shown to induce the release of several pro-inflammatory cytokines (e.g., TNF- $\alpha$ ) and chemotactic factors including IL-8 and monocyte chemoattractant protein (MCP)-1 [15,38]. However, the exact contribution of the MAC to the 


\section{0min MCAO: neurological deficit}
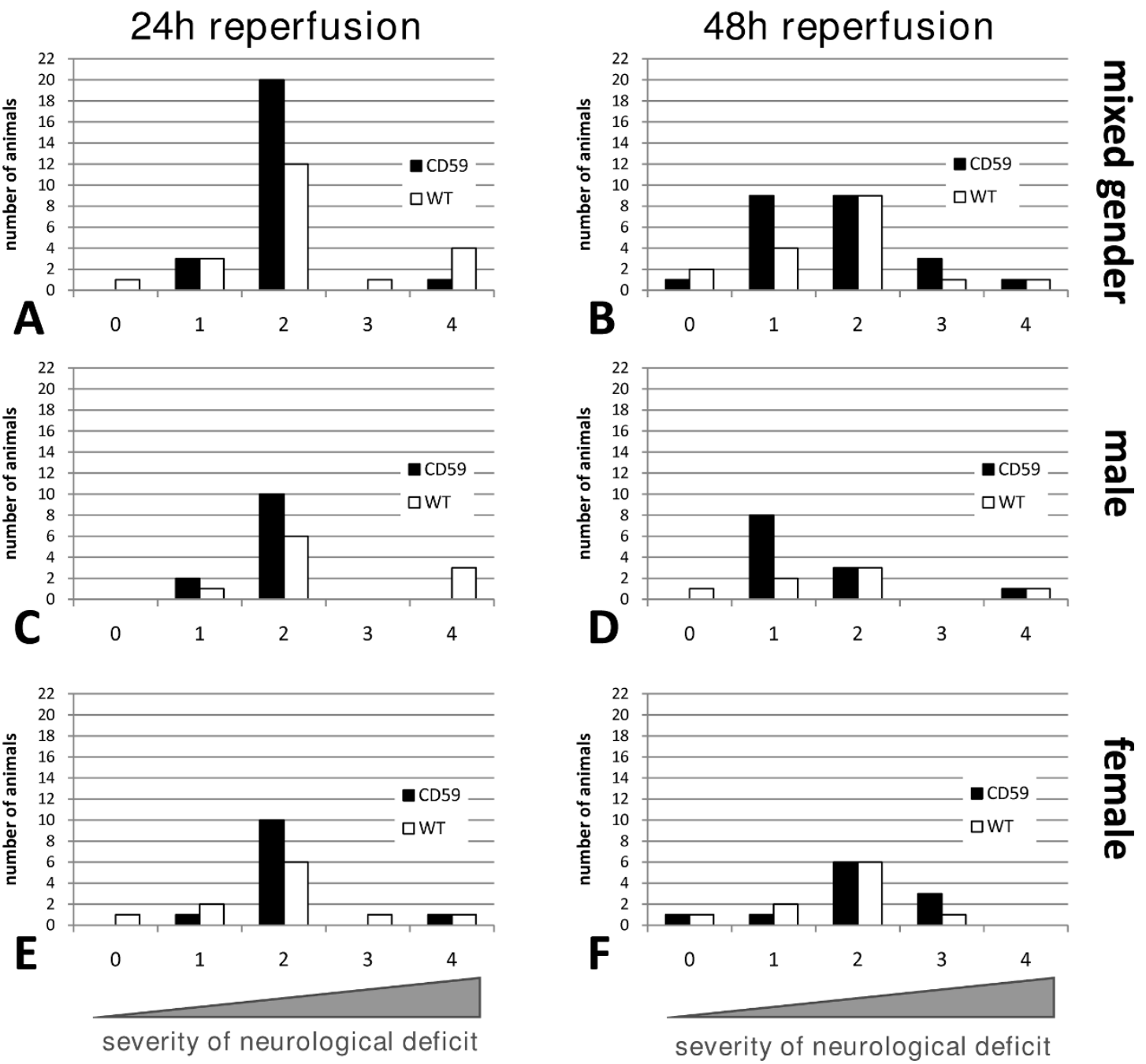

Figure 5 Comparison of neurological dysfunction of CD59a-deficient and wild-type-mice (C57BL/6) after 60 min MCAO. Either $24 \mathrm{~h}$ after reperfusion $(\mathbf{A}, \mathbf{C}, \mathbf{E})$ or $48 \mathrm{~h}$ after reperfusion $(\mathbf{B}, \mathbf{D}, \mathbf{F})$ there is no significant difference in neurological dysfunction, neither in male $(\mathbf{C}, \mathbf{D})$ nor in female (E, F) mice group when comparing CD59-deficient mice to wild-type (WT) mice. Statistical analysis was performed using the MannWhitney-U-test. Score of 0: no neurological dysfunctions; score 1: failure to extend right forepaw, score 2: circling to the contralateral side; score 3: loss of postural reflex and score 4: death. Number of animals: for CD59a-ko $n=24, W T n=21$. Both male and female animals were used in this study.

complement-mediated injury in cerebral ischemia has remained unclear. The complement regulator protein CD59 is known to inhibit MAC formation by preventing the incorporation and polymerization of $\mathrm{C} 9$ on cell membranes [13]. CD59a has been characterized as the primary regulator of MAC assembly in the mouse, since the expression of the second CD59 isoform in mice, CD59b, was found to be restricted to testis [39].

Thus, we used CD59a-deficient mice to study the role of MAC and its inhibitory protein CD59a in focal cerebral ischemia. Our data reveal that the presence of CD59a improves neurological outcome, decreases brain swelling, and reduces infarct volume after $30 \mathrm{~min}$ of transient focal cerebral ischemia in the mouse. We have previously shown an increased neurological deficit in CD59a-knockout mice when compared to wild-type mice in a model of traumatic brain injury [11]. Moreover, a stroke study in neonatal rats, naturally lacking C9 - which is part of the terminal MAC - demonstrated an increase of infarct volumes in neonatal rats when 


\section{0min MCAO: neurological deficit}
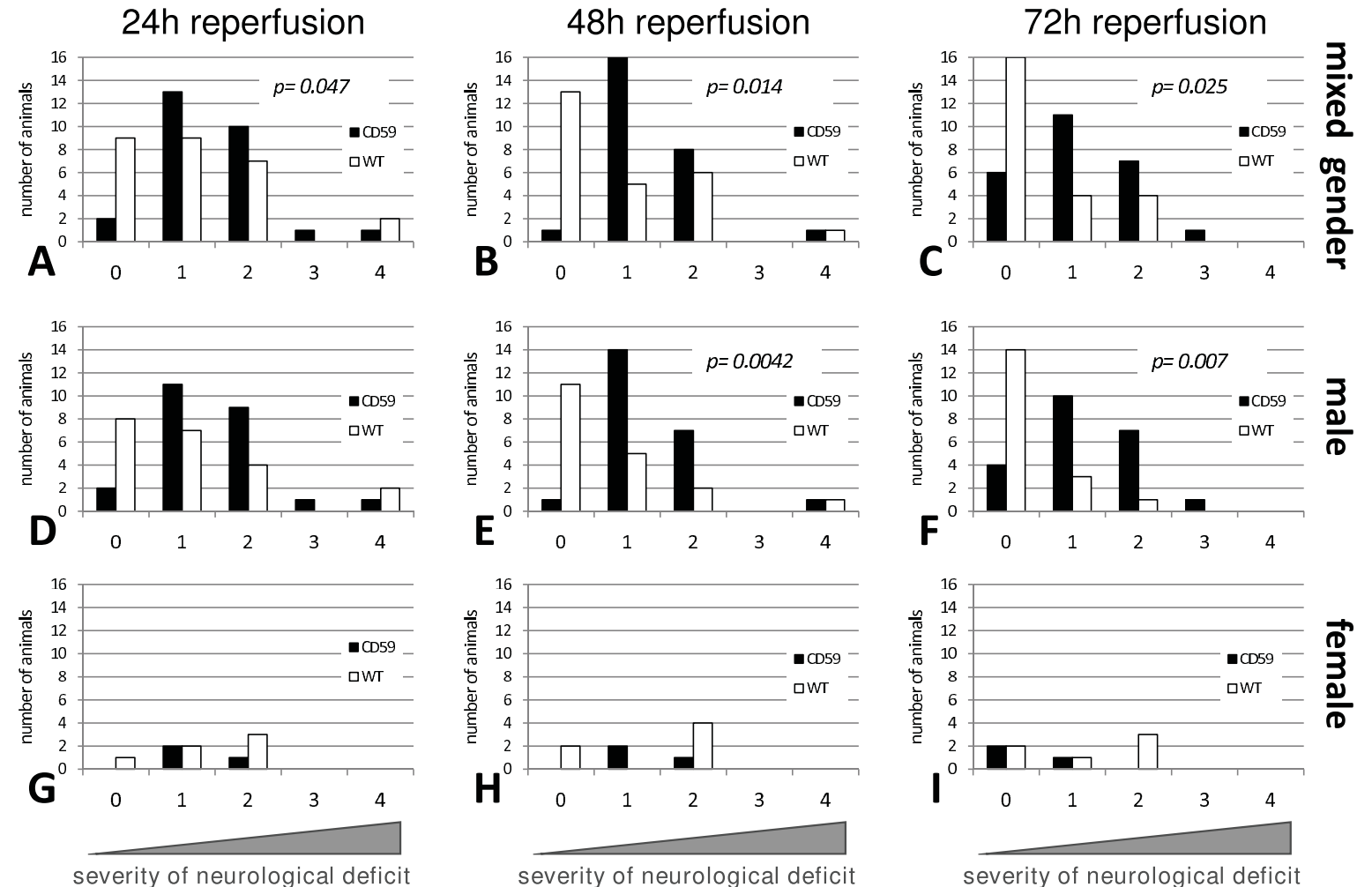

Figure 6 Comparison of neurological dysfunction of CD59a-deficient and wild-type-mice (C57BL/6) after $\mathbf{3 0}$ min MCAO. The CD59-kO mice in the mixed gender group show $24 \mathrm{~h}$ after reperfusion (A), $48 \mathrm{~h}$ after reperfusion $(\mathbf{B})$ and $72 \mathrm{~h}$ after reperfusion $(\mathbf{C})$ a significant increased neurological dysfunction ( $p<0,05)$ compared to wild-type (WT) mice. In the male gender group ( $\mathbf{D}, \mathbf{E}, \mathbf{F})$ there is only a significant difference

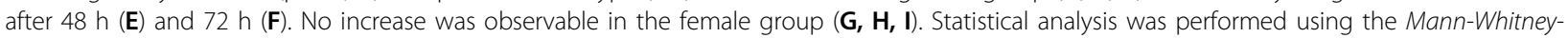
U-test. A score of 0 shows no neurological dysfunctions; score 1: failure to extend right forepaw, score 2: circling to the contralateral side; score 3: loss of postural reflex and score 4: death. Number of animals: for CD59a-ko $n=27, W T n=27$. Both male and female animals were used in this study.

purified C9 was injected [40]. Further, CD59 was shown to efficiently protect human NT2-N neuronal cells against complement-mediated cell injury [41,42].

Our data revealed that significant protection by the presence of CD59a is gender-specific and is only achieved in male mice. This difference might be explained by the influence of hormonal fluctuations in female mice. Gender-specific neuroprotective effects have been also found by others [43-45]. A substantial amount of data indicates that progesterone, a gonadal hormone and neurosteroid naturally distributed in the human brain, has potent neuroprotective properties $[46,47]$. In animal studies, progesterone reduced cerebral edema, neuronal loss and behavioral deficits by inhibiting secondary injury cascade [48-52]. Safety and efficacy phase I and II trials have been succesfully conducted in recent clinical trials $[53,54]$. It appears that the gender-specific neuroprotective effects seen in the present study may be related to progesteronemediated beneficial effects in female animals.
Moreover, the degree of protection by CD59a depends on the stroke model used and was only observed in the stroke model with the more selected neuronal death (mild stroke model). This observation fits well with the data of Yamada et al. [55], which observed only a synergistic effect of CD59a deficiency (together with CD55) in renal ischemia. The prolonged occlusion interval $(60 \mathrm{~min}$ MCAO) leads to a significant increase of TUNEL-positive cells in the CD59a-deficient mice when compared to wild-type mice, which is in good agreement with the findings of Turnberg et al. [20], who obtained similar results using CD59a-/- mice in a model of renal ischemia.

It was recently shown that ischemia leads to a rapid loss of membranous CD59 protein in the ischemic core region $[41,6]$. Thus, we alternatively speculate that the longer occlusion interval in the 60 min MCAO model may dampen local CD59a-expression, so that the remaining $C D 59$ a expression in the wild-type mice $(\mathrm{CD} 59 \mathrm{a}+/+)$ is of minor relevance when compared to 
the complete lack of CD59a expression in the knockout mice. An alternative explanation may be that both models (30 min vs. 60 min occlusion interval) are characterized by different degrees of complement activation: in the postischemic brain tissue of the 30 min MCAO model complement activation may only result in sublytic MAC-concentrations, so that the MAC-mediated effects not directly result in cell lysis (as it may be the case in the 60 min MCAO model), but rather contribute to the secondary brain injury by the induction of proinflammatory chemokines, which renders the postischemic damage more dependent on MAC-inhibition. We postulate that CD59a-deficiency mainly contributes to postischemic neuronal damage by increasing MAC-induced neuronal cell death, but that this effect is further increased by the modulation of the innate immune system (invading leukoycytes as well as activated glia) as reviewed by Griffiths et al. (2009) [56]. Nevertheless, the different reperfusion intervals in both models used do not allow a direct comparison of infarct outcomes. Accordingly, effects of CD59a-deficiency differ significantly in renal ischemia, depending on the time point used for evaluation $[20,55]$.

MAC formation was recently shown to trigger up-regulation of pro-inflammatory cytokines, chemotactic factors, as well as adhesion molecules such as P-Selectin, E-selectin and ICAM-1 in activated endothelial cells $[15,30,38]$. Nevertheless, we did not detect a significant increase of the inflammatory cell accumulation in the CD59a-deficient mice when compared to wild-type mice. This observation may be due to the more prominent effect of other chemoattractant proteins, which were upstream of the MAC in the complement cascade (e.g. C3a, C5a), and which were not affected by CD59a expression. An alternative explanation may be that the part of the inflammatory response which is based on the MAC-driven induction of pro-inflammatory genes is not detected at the time points studied in our setting and may be more relevant at earlier time points as observed by [57].

Nevertheless, our study is in good agreement with various reports, that show an improved neurological function after experimental stroke in animals treated with complement-inhibitors [33], treated with the complement-depleting agent cobra venom factor [58,9], or in animals which lack complement components, e.g. C3deficient mice [59]. The ongoing debate of whether the complement system is 'friend or foe' in ischemic brain injury [60] may be explained by the complexity of the system and the manifold pathways which are activated by the complement system, and the different ways complement may be inhibited at different levels of the complement cascade. Thus, our data which demonstrates model- and gender-specific effects of MAC-inhibition by
CD59a, replenishes the current understanding of the complement system in ischemic brain injury and thus may contribute to the development of future therapeutical strategies [61].

\section{Conclusions}

Based on the data, we conclude that the complement inhibitor protein CD59 is protective after cerebral ischemia in a gender specific way, and that this effect depends on the severity of the cerebral damage. In a mild model of cerebral ischemia with selective neuronal cell death, CD59 leads to less neuronal dysfunction and a smaller infarct volume. However, the exact mechanisms of complement MAC-induced neuronal cell death after cerebral ischemia require further investigation.

\section{Acknowledgements}

This work was supported by the Deutsche Forschungsgemeinschaft (DFG grant Tr742/1-1,2)

\section{Author details}

${ }^{1}$ Experimentelle Neurologie, Charité-Universitätsmedizin Berlin, CCM, 10117, Berlin, Germany. ${ }^{2}$ Dept. of Orthopaedic Surgery and Dept. of Neurosurgery, Denver Health Medical Center, University of Colorado School of Medicine, 777 Bannock Street, CO, 80204 Denver, USA. Department of Infection, Immunity and Biochemistry, School of Medicine, Cardiff University, Cardiff CF14 4XN, UK. ${ }^{4}$ Max-Planck-Institute for Molecular Genetics, Ihnestr.73, 14195 Berlin, Germany.

\section{Authors' contributions}

$\mathrm{DH}$ designed the experiments, performed all experiments, analysed the data, generated the figures, and wrote the manuscript. UK did parts of the animal surgery and revised the manuscript. PFS, BPM, and WN participated in the experimental design, and in the editing of the manuscript. UD provided overall study supervision and intellectual input. GT participated in the experimental design and preparation of the manuscript. All authors have read and approved the manuscript.

\section{Competing interests}

The authors declare that they have no competing interests.

Received: 7 January 2010

Accepted: 4 March 2010 Published: 4 March 2010

\section{References}

1. Dirnagl U, ladecola C, Moskowitz MA: Pathobiology of ischaemic stroke: an integrated view. Trends Neurosci 1999, 22:391-397.

2. Hossmann KA: Pathophysiology and Therapy of Experimental Stroke. Cell Mol Neurobiol 2006, 26:1055-1081.

3. McColl BW, Rothwell NJ, Allan SM: Systemic Inflammation Alters the Kinetics of Cerebrovascular Tight Junction Disruption after Experimental Stroke in Mice. J Neurosci 2008, 28:9451-9462.

4. Trendelenburg G: Acute neurodegeneration and the inflammasome: central processor for danger signals and the inflammatory response? J Cereb Blood Flow Metab 2008, 28:867-881.

5. Ducruet AF, Zacharia BE, Hickman ZL, Grobelny BT, Yeh ML, Sosunov SA, Connolly ES Jr: The complement cascade as a therapeutic target in intracerebral hemorrhage. Exp Neurol 2009, 219:398-403.

6. Pedersen ED, Løberg EM, Vege E, Daha MR, Maehlen J, Mollnes TE: In situ deposition of complement in human acute brain ischaemia. Scand J Immunol 2009, 69:555-562.

7. Komotar RJ, Starke RM, Arias EJ, Garrett MC, Otten ML, Merkow MB, Hassid B, Mocco J, Sughrue ME, Kim GH, Mack WJ, Ducruet AF, Connolly ES: The Complement Cascade: New Avenues in Stroke Therapy. Curr VasC Pharmacol 2009, 7:287-292. 
8. Széplaki G, Szegedi R, Hirschberg K, Gombos T, Varga L, Karádi I, Entz L, Széplaki Z, Garred P, Prohászka Z, Füst G: Strong complement activation after acute ischemic stroke is associated with unfavorable outcomes. Atherosclerosis 2009, 204:315-20.

9. Figueroa E, Gordon LE, Feldhoff PW, Lassiter HA: The administration of cobra venom factor reduces post-ischemic cerebral injury in adult and neonatal rats. Neurosci Lett 2005, 380:48-53.

10. Storini C, Rossi E, Marrella V, Distaso M, Veerhuis R, Vergani C, Bergamaschini L, De Simoni MG: C1-inhibitor protects against brain ischemia-reperfusion injury via inhibition of cell recruitment and inflammation. Neurobiol Dis 2006, 19:10-17.

11. Stahel P, Flierl M, Morgan BP, Persigehl I, Stoll C, Conrad C, Touban B, Smith W, Beauchamp K, Schmidt O, Ertel W, Leinhase I: Absence of the complement regulatory molecule CD59a leads to exacerbated neuropathology after traumatic brain injury in mice. J Neuroinflammation 2009, 6:2.

12. Sugita $Y$, Masuho $Y$ : CD59: its role in complement regulation and potential for therapeutic use. Immunotechnol 1995, 1:157-168.

13. Meri S, Morgan BP, Davies A, Daniels RH, Olavesen MG, Waldmann H, Lachmann PJ: Human protectin (CD59), an 18,000-20,000 MW complement lysis restricting factor, inhibits $\mathrm{C} 5 \mathrm{~b}-8$ catalysed insertion of C9 into lipid bilayers. Immunology 1990, 71:1-9.

14. Morgan BP: Complement membrane attack on nucleated cells: resistance, recovery and non-lethal effects. Biochem J 1999, 264:1-14.

15. Kilgore KS, Flory CM, Miller BF, Evans VM, Warren JS: The membrane attack complex of complement induces interleukin-8 and monocyte chemoattractant protein-1 secretion from human umbilical vein endothelial cells. Am J Pathol 1996, 149:953-61.

16. Wu G, Hu W, Shahsafaei A, Song W, Dobarro M, Sukhova GK, Bronson RR, Shi GP, Rother RP, Halperin JA, Qin X: Complement regulator CD59 protects against atherosclerosis by restricting the formation of complement membrane attack complex. Circ Res 2009, 104:550-8.

17. Xiong ZQ, Qian W, Suzuki K, McNamara JO: Formation of complement membrane attack complex in mammalian cerebral cortex evokes seizures and neurodegeneration. J Neurosci 2003, 23:955-60.

18. Holt DS, Botto M, Bygrave AE, Hanna SM, Walport MJ, Morgan BP: Targeted deletion of the CD59 gene causes spontaneous intravascular hemolysis and hemoglobinuria. Blood 2001, 98:442-449.

19. Trendelenburg M: Complement inhibition by anti- $\mathrm{C} 5$ antibodies-from bench to bedside and back again. Swiss Med Wkly 2007, 137:413-7.

20. Turnberg D, Botto M, Lewis M, Zhou W, Sacks SH, Morgan BP, Walport MJ, Cook HT: CD59a Deficiency Exacerbates Ischemia-Reperfusion Injury in Mice. Am J Pathol 2004, 165:825-832.

21. van Beek J, van Meurs M, 't Hart BA, Brok HPM, Neal JW, Chatagner A, Harris CL, Omidvar N, Morgan BP, Laman JD, Gasque P: Decay-Accelerating Factor (CD55) Is Expressed by Neurons in Response to Chronic but Not Acute Autoimmune Central Nervous System Inflammation Associated with Complement Activation. J Immunol 2005, 174:2353-2365.

22. Singhrao SK, Neal JW, Rushmere NK, Morgan BP, Gasque P: Spontaneous classical pathway activation and deficiency of membrane regulators render human neurons susceptible to complement lysis. Am J Pathol 2000, 157:905-18.

23. Hara H, Huang PL, Panahian N, Fishman MC, Moskowitz MA: Reduced Brain Edema and Infarction Volume in Mice Lacking the Neuronal Isoform of Nitric Oxide Synthase After Transient MCA Occlusion. J Cereb Blood Flow Metab 1996, 16:605-611.

24. Katchanov J, Waeber C, Gertz K, Gietz A, Winter B, Brück W, Dirnagl U, Veh RW, Endres M: Selective neuronal vulnerability following mild focal brain ischemia in the mouse. Brain Pathol 2003, 13:452-64.

25. Dirnagl U, Members of the MCAO-SOP Group: Standard operating procedures (SOP) in experimental stroke research: SOP for middle cerebral artery occlusion in the mouse. Nature Precedings 2009http://hdl. handle.net/10101/npre.2009.3492.1.

26. Bederson JB, Pitts LH, Tsuji M, Nishimura MC, Davis RL, Bartkowski H: Rat middle cerebral artery occlusion: evaluation of the model and development of a neurologic examination. Stroke 1986, 17:472-476.

27. Uitenbroek DG: SISA-Binomial. 1997http://www.quantitativeskills.com/sisa/ calculations/power.htm.

28. Cohen J: Statistical power analysis for the behavioral sciences. Lawrence Erlbaum Associates, Mahwah, NJ, 21988.
29. Gertz K, Priller J, Kronenberg G, Fink KB, Winter B, Schröck H, Ji S, Milosevic M, Harms C, Böhm M, Dirnagl U, Laufs U, Endres M: Physical activity improves long-term stroke outcome via endothelial nitric oxide synthase-dependent augmentation of neovascularization and cerebral blood flow. Circ Res 2006, 99:1132-40.

30. Kilgore KS, Schmid E, Shanley TP, Flory CM, Maheswari V, Tramontini NL, Cohen H, Ward PA, Friedl HP, Warren JS: Sublytic concentrations of the membrane attack complex of complement induce endothelial interleukin-8 and monocyte chemoattractant protein-1 through nuclear factor-kappa B activation. Am J Pathol 1997, 150:2019-31.

31. Lucas SM, Rothwell NJ, Gibson RM: The role of inflammation in CNS injury and disease. Br J Pharmacol 2006, 1(147 Suppl):232-40.

32. Arumugam TV, Magnus T, Woodruff TM, Proctor LM, Shiels IA, Taylor SM: Complement mediators in ischemia-reperfusion injury. Clinica Chimica Acta 2006, 374:33-45.

33. Arumugam TV, Woodruff TM, Lathia JD, Selvaraj PK, Mattson MP, Taylor SM: Neuroprotection in stroke by complement inhibition and immunoglobulin therapy. Neuroscience 2009, 158:1074-1089.

34. Buerke M, Prüfer D, Dahm M, Oelert H, Meyer J, Darius H: Blocking of classical complement pathway inhibits endothelial adhesion molecule expression and preserves ischemic myocardium from reperfusion injury. J Pharmacol Exp Ther 1998, 286:429-38.

35. Chan RK, Ibrahim SI, Takahashi K, Kwon E, McCormack M, Ezekowitz A, Carroll MC, Moore FD Jr, Austen WG Jr: The differing roles of the classical and mannose-binding lectin complement pathways in the events following skeletal muscle ischemia-reperfusion. J Immunol 2006, 177:8080-5.

36. Leinhase I, Holers VM, Thurman JM, Harhausen D, Schmidt OI, Pietzcker M, Taha ME, Rittirsch D, Huber-Lang M, Smith WR, Ward PA, Stahel PF: Reduced neuronal cell death after experimental brain injury in mice lacking a functional alternative pathway of complement activation. $B M C$ Neurosci 2006, 7:55.

37. Leinhase I, Rozanski M, Harhausen D, Thurman JM, Schmidt OI, Hossini AM, Taha ME, Rittirsch D, Ward PA, Holers VM, Ertel W, Stahel PF: Inhibition of the alternative complement activation pathway in traumatic brain injury by a monoclonal anti-factor $B$ antibody: a randomized placebocontrolled study in mice. J Neuroinflammation 2007, 4:3.

38. Tramontini N, Kuipers P, Huber C, Murphy K, Naylor K, Broady A, Kilgore K: Modulation of Leukocyte Recruitment and IL-8 Expression by the Membrane Attack Complex of Complement (C5b-9) in a Rabbit Model of Antigen-Induced Arthritis. Inflammation 2002, 26:311-319.

39. Baalasubramanian S, Harris CL, Donev RM, Mizuno M, Omidvar N, Song WC, Morgan BP: CD59a Is the Primary Regulator of Membrane Attack Complex Assembly in the Mouse. J Immunol 2004, 173:3684-3692.

40. Imm MD, Feldhoff PW, Feldhoff RC, Lassiter HA: The administration of complement component C9 augments post-ischemic cerebral infarction volume in neonatal rats. Neurosci Lett 2002, 325:175-178.

41. Pedersen ED, Frøyland E, Kvissel AK, Pharo AM, Skåslhegg BrS, Rootwelt T, Mollnes TE: Expression of complement regulators and receptors on human NT2-N neurons-Effect of hypoxia and reoxygenation. $\mathrm{Mol}$ Immunol 2007, 44:2459-2468.

42. Pedersen ED, Aass HC, Rootwelt T, Fung M, Lambris JD, Mollnes TE: CD59 efficiently protects human NT2-N neurons against complementmediated damage. Scand J Immunol 2007, 66:345-51.

43. Chen $\mathrm{CH}$, Toung $\mathrm{TJ}$, Hurn PD, Koehler RC, Bhardwaj A: Ischemic neuroprotection with selective kappa-opioid receptor agonist is gender specific. Stroke 2005, 36:1557-61.

44. Nijboer $\mathrm{CH}$, Groenendaal F, Kavelaars A, Hagberg HH, van Bel F, Heijnen C: Gender-specific neuroprotection by 2-iminobiotin after hypoxia-ischemia in the neonatal rat via a nitric oxide independent pathway. $J$ Cereb Blood Flow Metab 2007, 27:282-92.

45. Palmon SC, Williams MJ, Littleton-Kearney MT, Traystman RJ, Kosk-Kosicka D, Hurn PD: Estrogen increases CGMP in selected brain regions and in cerebral microvessels. J Cereb Blood Flow Metab 1998, 18:1248-52.

46. Behl C: Oestrogen as a neuroprotective hormone. Nat Rev Neurosci 2002, 3:433-442.

47. Roof RL, Hoffman SW, Stein DG: Progesterone protects against lipid peroxidation following traumatic brain injury in rats. Mol Chem Neuropathol 1997, 31:1-11.

48. Asbury ET, Fritts ME, Horton JE, Isaac WL: Progesterone facilitates the acquisition of avoidance learning and protects against subcortical 
neuronal death following prefrontal cortex ablation in the rat. Behav Brain Res 1098, 97:99-106.

49. Pettus EH, Wright DW, Stein DG, Hoffman SW: Progesterone treatment inhibits the inflammatory agents that accompany traumatic brain injury. Brain Res 2005, 1049:112-119.

50. Roof RL, Duvdevani R, Heyburn JW, Stein DG: Progesterone rapidly decreases brain edema: treatment delayed up to 24 hours is still effective. Exp Neurol 1996, 138:246-251.

51. Shear DA, Galani R, Hoffman SW, Stein DG: Progesterone protects against necrotic damage and behavioral abnormalities caused by traumatic brain injury. Exp Neurol 2002, 178:59-67.

52. Thomas AJ, Nockels RP, Pan HQ, Shaffrey Cl, Chopp M: Progesterone is neuroprotective after acute experimental spinal cord trauma in rats. Spine 1999, 24:2134-2138.

53. Wright DW, Ritchie JC, Mullins RE, Kellermann AL, Denson DD: Steady-state serum concentrations of progesterone following continuous intravenous infusion in patients with acute moderate to severe traumatic brain injury. J Clin Pharmacol 2005, 45:640-648.

54. Wright DW, Kellermann AL, Hertzberg VS, Clark PL, Frankel M, Goldstein FC, Salomone JP, Dent LL, Harris OA, Ander DS, Lowery DW, Patel MM, Denson DD, Gordon AB, Wald MM, Gupta S, Hoffman SW, Stein DG PrOTECT: a randomized clinical trial of progesterone for acute traumatic brain injury. Ann Emerg Med 2007, 49:391-402, 402 e391-392.

55. Yamada K, Miwa T, Liu J, Nangaku M, Song WC: Critical protection from renal ischemia reperfusion injury by CD55 and CD59. J Immunol 2004, 172:3869-75

56. Griffiths MR, Gasque P, Neal JW: The multiple roles of the innate immune system in the regulation of apoptosis and inflammation in the brain. J Neuropathol Exp Neurol 2009, 68:217-26.

57. Ramaglia V, King RH, Morgan BP, Baas F: Deficiency of the complement regulator CD59a exacerbates Wallerian degeneration. Mol Immunol 2009, 46:1892-6.

58. Cowell RM, Plane JM, Silverstein FS: Complement activation contributes to hypoxic-ischemic brain injury in neonatal rats. J Neurosci 2003, 23:9459-68.

59. Atkinson C, Zhu H, Qiao F, Varela JC, Yu J, Song H, Kindy MS, Tomlinson S: Complement-Dependent P-Selectin Expression and Injury following Ischemic Stroke. J Immunol 2006, 177:7266-7274.

60. del Zoppo GJ: In stroke, complement will get you nowhere. Nat Med 1999, 5:995-6.

61. Kolev MV, Tediose T, Sivasankar B, Harris CL, Thome J, Morgan BP, Donev RM: Upregulating CD59: a new strategy for protection of neurons from complement-mediated degeneration. Pharmacogenomics J 2010, 10:12-9.

doi:10.1186/1742-2094-7-15

Cite this article as: Harhausen et al: Membrane attack complex inhibitor CD59a protects against focal cerebral ischemia in mice. Journal of Neuroinflammation 2010 7:15.

\section{Submit your next manuscript to BioMed Central and take full advantage of:}

- Convenient online submission

- Thorough peer review

- No space constraints or color figure charges

- Immediate publication on acceptance

- Inclusion in PubMed, CAS, Scopus and Google Scholar

- Research which is freely available for redistribution

Submit your manuscript at www.biomedcentral.com/submit
CioMed Central 